\title{
MEDICAL COMPLIANCE DETERMINANTS FOR TUBERCULOSIS PATIENTS IN PALEMBANG
}

\author{
Uca Ayu Frama Diesty, RM.Suryadi Tjekyan, M.Zulkarnain \\ Bukit Besar, Jl. Padang Selasa No.524, Bukit Lama, Ilir Barat. I Distric, Palembang, South Sumatera, 30139 \\ Indonesia
}

\begin{abstract}
The majority of countries in the world have tuberculosis, including Indonesia, which has the third rank in the world. This is due to a large number of sufferers who were not successfully cured. One of the factors that influence the recovery of tuberculosis patients is adherence to taking anti-tuberculosis drugs for a certain period of time. Non-adherence to treatment can exacerbate the risk of disease because it can lead to MDR (Multi Drugs Resistant) tuberculosis. This study aims to analyze the determinants of tuberculosis treatment compliance in the city of Palembang. This study used an analytical study with a semi-quantitative approach, with a cross-sectional design. Sampling was carried out by proportional random sampling at 39 Puskesmas Kota Palembang, a total of 243 samples that met the inclusion and exclusion criteria. Data collection was carried out by means of interviews using a questionnaire. Data were analyzed using the chi-square test and multiple logistic regression. Obtained adherence to treatment of tuberculosis patients by $42.8 \%$. There was a significant relationship between perceived benefits ( $p=0.000 ;$ OR $=3.556)$, family support $(p=0.000 ;$ OR $=3.512)$, support from health workers $(p=0.001 ; O R=2.712)$, knowledge $(p=0.018 ; O R=2,027)$ with adherence to treatment of tuberculosis patients. The level of compliance with tuberculosis patients in Palembang City is still low, namely 42.8\%. The most important determinant of adherence is perceived benefit with a 3.556 times greater opportunity after controlling for other variables.
\end{abstract}

Keywords: Tuberculosis, compliance, determinants

\begin{abstract}
ABSTRAK
Mayoritas negara di dunia memiliki penyakit tuberculosis termasuk di Indonesia yang menduduki peringkat ketiga sedunia. Hal ini disebabkan banyaknya penderita yang tidak berhasil disembuhkan. Salah satu faktor yang mempengaruhi kesembuhan pasien tuberculosis adalah kepatuhan minum obat anti tuberculosis selama periode waktu tertentu. Ketidakpatuhan terhadap pengobatan dapat memperparah resiko penyakit karenadapat mengakibatkan kejadian tuberculosis MDR(Multi Drugs Resistant). Penelitian ini bertujuan untuk mengetahui determinan kepatuhan berobat penderita tuberculosis di Kota Palembang. Penelitian ini menggunakanpenelitian analitik dengan pendekatan semi kuantitatif, dengan rancangan cross sectional. Pengambilan sampel dilakukan dengan proportional random sampling di 39 Puskesmas Kota Palembang, sebanyak 243 sampel yang memenuhi kriteria inklusi dan eksklusi.Pengumpulan data dilakukan dengan cara wawancara menggunakan kuesioner. Data dianalisis dengan menggunakan uji chi square dan regresi logistik ganda. Didapatkan kepatuhan berobat pasien tuberculosis sebesar 42,8\%. Terdapat hubungan yang signifikan antara persepsi manfaat $(p=0,000 ; \mathrm{OR}=3,556)$, dukungan keluarga $(p=0,000 ; \mathrm{OR}=3,512)$, dukungan petugas kesehatan $(p=0,001 ; \mathrm{OR}=2,712)$, pengetahuan $(p=0,018 ; \mathrm{OR}=2,027)$ dengan kepatuhan berobat pasien tuberculosis. Tingkat kepatuhan berobat pasien tuberculosis di Kota Palembang masih rendah yaitu $42,8 \%$. Determinan kepatuhan yang paling utama adalah persepsi manfaat berpeluang 3,556 kali lebih besar setelah di kontrol variabel lain.
\end{abstract}

Kata Kunci : Tuberculosis, kepatuhan, determinan 


\section{Introduction}

WHO has declared a global emergency for tuberculosis because tuberculosis is out of control in most countries in the world. This is due to the large number of patients who have not been successfully cured, especially those who are infectious (smear-positive). ${ }^{1}$ For tuberculosis, Indonesia Third ranks in the world. In Indonesia, it is estimated that every year 150 thousand people die caused by tuberculosiss. ${ }^{2}$

The dropout rate of TB patients in Indonesia is $4.1 \%$ of 294,732 TB cases, which is consist of 12.084 people. ${ }^{3}$ Based on the annual report on the results of treatment of TB patients in South Sumatra Province in 2012, the dropout rate for TB patients was $4.14 \%$ (218 people), while for the city of Palembang the dropout rate for TB patients in 2012 was $4.019 \%$ (52 people). The dropout rate can be reduced if there is an attention from the patient's environment to remind them about medication which calls Drug Administration Supervisor (PMO).

A large number of TB cases caused by the high dropout rate, and the low number of PMOs pose a risk for non-compliance and exacerbate the risk of disease for TB patients, named the occurrence of MDR (Multi Drugs resistant) TB. MDR TB treatment was more difficult than the TB treatment which is still sensitive. MDR TB can be cured although it takes a longer time, namely 18-24 months.

Tuberculosis patient recovery is affected by adherence to taking anti-tuberculosis drugs for a certain period of time. Tuberculosis treatment must be carried out by the patient for a period of six months. Treatment with a long time and the consumption of drugs that must be done every day allows patients to dropout or not adhere to treatment. ${ }^{4}$

Therefore it is necessary to know how adherence to treatment of tuberculosis patients in Palembang City is to reduce the risk of MDR TB which requires longer time and more expensive medical costs so that researchers are interested in knowing the determinants of tuberculosis patient treatment compliance in Palembang. This study aims to analyze the determinants of tuberculosis treatment compliance in the city of Palembang.

\section{Method}

This research is an analytical study with a semi-quantitative approach. This research is an analytic observational study using a cross-sectional research method, namely studying the correlation between individual characteristics factors, previous behavior, specific behavior, and interpersonal behavior with treatment compliance of pulmonary TB patients in Palembang.

The population in this study were all pulmonary TB patients who were registered in the TB treatment register in Palembang totaling 1,247 people. The sample consisted of 243 patients with pulmonary tuberculosis who were registered in the TB treatment register at the Public Health 
Center of Palembang, which was obtained from the formula for calculating the sample size of the hypothesis test for two population proportions (Lameshow, 1977) who had met the inclusion and exclusion criteria. Sampling was done by proportional random sampling. ${ }^{5}$ Primary data collection was obtained by interviewing using a questionnaire. ${ }^{6}$

The dependent variable of this research is compliance with tuberculosis patient treatment and the independent variables of this study are individual characteristics (age, sex, marital status, occupation, education), previous behavior (knowledge, attitudes, history/complaints of pulmonary tuberculosis, perceptions of health status), specific behaviors (perceived self-efficacy, perceived barriers, perceived benefits, perceived threats/dangers), and interpersonal support (family support, advice for treatment, support from health workers, presence of PMO, and the influence of the social environment).

Analysis of the data in this study used univariate, bivariate analysis with chi-square and multiple logistic regression using the Backward $L R$ method to see the determinants that most influence on compliance with tuberculosis patients treatment, then interpret the results of the analysis and create an equation model. Because the research design used was cross-sectional, the size of the association used in this study was POR (Prevalence Odds Ratio) with the same formula as OR. With the complete OR, P and CI values, variables that have OR at 95\% CI and p-value $<0.25$ can be considered to be included in the multivariate model (multivariate analysis), which is used is Unconditional Logistic Regression Analysis.

\section{Results}

The results of this study obtained $42.8 \%$ compliance with tuberculosis patients treated in Palembang. The complete distribution of treatment adherence is shown in table 1 below:

Table 1. Distribution of Patients according to Treatment Adherence

\begin{tabular}{ccc}
\hline \multirow{2}{*}{ Adherence } & \multicolumn{2}{c}{ Total } \\
\cline { 2 - 3 } & $\mathbf{N}$ & $\mathbf{\%}$ \\
\hline Not Adhere & 139 & 57,2 \\
Adhere & 104 & 42,8 \\
\hline Total & 243 & $100 \%$ \\
\hline
\end{tabular}

The univariate analysis carried out on 18 variables can be seen in Table 2 below: 
Table 2. Univariate Analysis of Determinants of Adherence to Treatment of Tuberculosis Patients

\begin{tabular}{|c|c|c|}
\hline \multirow{2}{*}{ Variable } & \multicolumn{2}{|c|}{ Total } \\
\hline & $\mathbf{N}$ & Percentage \\
\hline \multicolumn{3}{|l|}{ Gender } \\
\hline Male & 153 & $63 \%$ \\
\hline Female & 90 & $37 \%$ \\
\hline \multicolumn{3}{|l|}{ Age } \\
\hline Adult (17-44 th) & 99 & $40,7 \%$ \\
\hline Old $(>44$ th) & 144 & $59,3 \%$ \\
\hline \multicolumn{3}{|l|}{ Marital Status } \\
\hline Single & 55 & $22,6 \%$ \\
\hline Married & 188 & $77,4 \%$ \\
\hline \multicolumn{3}{|l|}{ Job } \\
\hline Employed & 109 & $44,9 \%$ \\
\hline Jobless & 134 & $55,1 \%$ \\
\hline \multicolumn{3}{|l|}{ Education } \\
\hline High & 95 & $39,1 \%$ \\
\hline Low & 148 & $60,9 \%$ \\
\hline \multicolumn{3}{|l|}{ Knowledge } \\
\hline Good & 99 & $40,7 \%$ \\
\hline Not good & 144 & $59,3 \%$ \\
\hline \multicolumn{3}{|l|}{ Attitude } \\
\hline Good & 190 & $78,2 \%$ \\
\hline Not good & 53 & $21,8 \%$ \\
\hline \multicolumn{3}{|l|}{ History / Complaints of TB } \\
\hline There is & 173 & $71,2 \%$ \\
\hline There is no & 70 & $28,8 \%$ \\
\hline \multicolumn{3}{|l|}{ Perceptions of Health Status } \\
\hline Good & 176 & $72,4 \%$ \\
\hline Not good & 67 & $27,6 \%$ \\
\hline \multicolumn{3}{|l|}{ Threat Perception } \\
\hline There is & 190 & $78,2 \%$ \\
\hline There is no & 53 & $21,8 \%$ \\
\hline \multicolumn{3}{|l|}{ Perceived Benefits } \\
\hline There is & 129 & $53,1 \%$ \\
\hline There is no & 114 & $46,9 \%$ \\
\hline \multicolumn{3}{|l|}{ Perception of Barriers } \\
\hline There is & 190 & $78,2 \%$ \\
\hline There is no & 53 & $21,8 \%$ \\
\hline \multicolumn{3}{|l|}{ Perception of Self Efficacy } \\
\hline Good & 168 & $69,1 \%$ \\
\hline Not good & 75 & $30,9 \%$ \\
\hline \multicolumn{3}{|l|}{ Medical advice } \\
\hline There is & 115 & $47,3 \%$ \\
\hline There is no & 128 & $52,7 \%$ \\
\hline \multicolumn{3}{|l|}{ Social Environmental Support } \\
\hline There is & 124 & $51,0 \%$ \\
\hline There is no & 119 & $49,0 \%$ \\
\hline \multicolumn{3}{|l|}{ Drug Ingestion Supervisor } \\
\hline There is & 97 & $39,9 \%$ \\
\hline There is no & 146 & $60,1 \%$ \\
\hline \multicolumn{3}{|l|}{ Family support } \\
\hline There is & 157 & $64,6 \%$ \\
\hline There is no & 86 & $35,4 \%$ \\
\hline \multicolumn{3}{|l|}{ Health Officer Support } \\
\hline There is & 119 & $49,0 \%$ \\
\hline There is no & 124 & $51,0 \%$ \\
\hline
\end{tabular}

The results of the bivariate analysis using the Chi-Square test to determine the determinants of tuberculosis patient treatment compliance in full are presented in table 3 below: 
Table 3. Bivariate Analysis of Determinants of Adherence to Treatment of Tuberculosis Patients

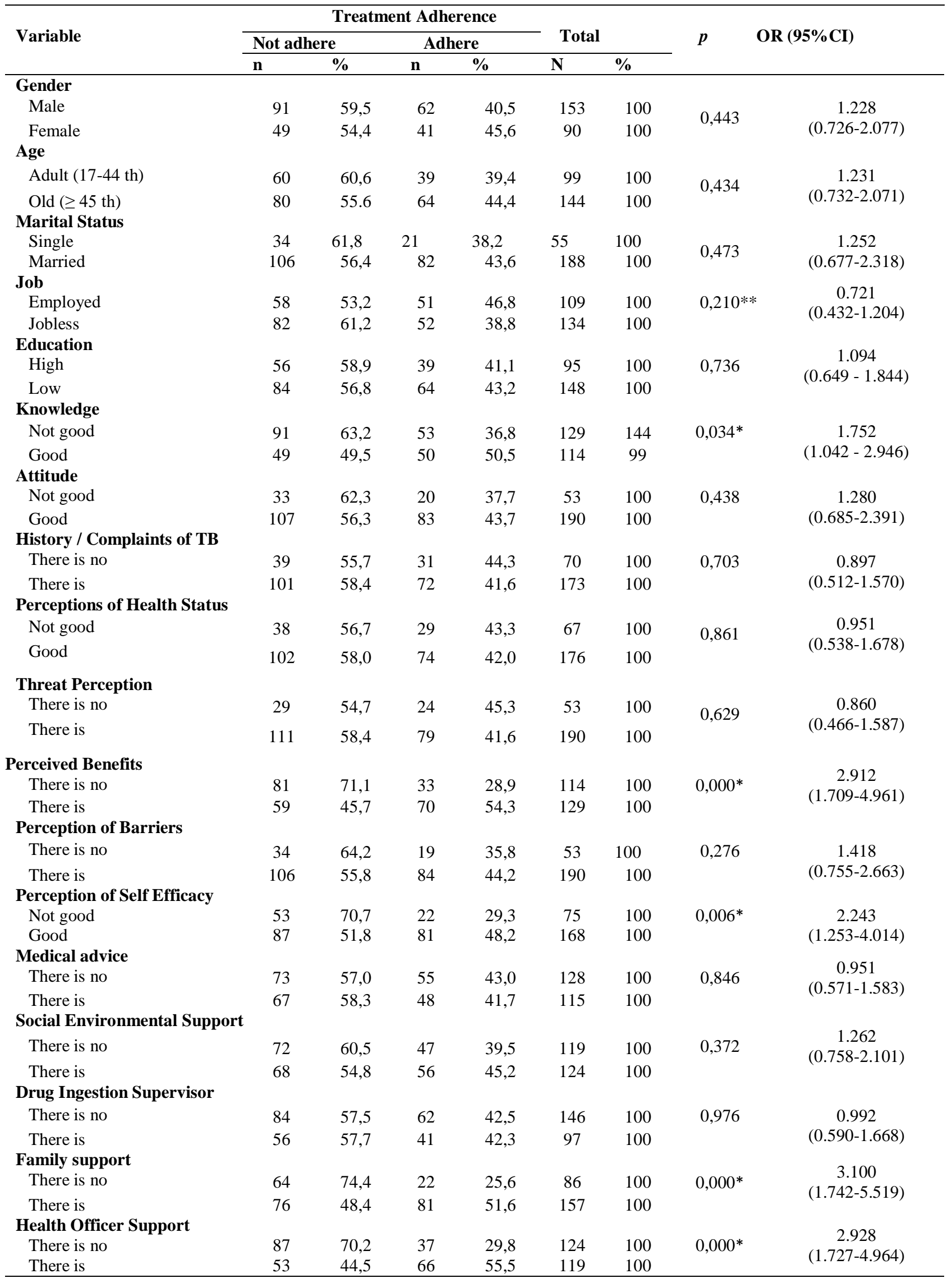


Information:

* significant, $\mathrm{p}$ value $<0.05$

** $\mathrm{p}$ value $<0.25$

In the multivariate analysis, variables were taken which in the bivariate analysis obtained pvalue $<0.25$. Table 3 shows the results of the Chi-Square analysis where there are variables that get a p-value $<0.25$, including variables of employment, knowledge, perceived threats, perceived benefits, family support, and support from health workers. These six variables will be included in the multivariate analysis. The Complete is presented in table 4 below:

Table 4. Candidate Model of Treatment Compliance for Pulmonary Tuberculosis Patients

\begin{tabular}{lc}
\hline \multicolumn{1}{c}{ Variable } & $P$-Value \\
\hline Job & 0,21 \\
Knowledge & 0,034 \\
Perceived Benefits & 0 \\
Perception of Self Efficacy & 0 \\
Family support & 0 \\
Health Officer Support & 0 \\
\hline
\end{tabular}

The results of the multivariate analysis using logistic regression showed that the predictor variables of treatment adherence after being analyzed together were known to be 4 variables that had an effect on treatment compliance, namely perceived benefits, family support, support from health workers, and knowledge. Details are presented in table 5 below:

\begin{tabular}{lccc}
\hline Variable & B & Sig & OR (95\% CI Exp B) \\
\hline Perceived Benefits & 1,269 & 0 & $3.556(1.965-6.435)$ \\
Family support & 1,256 & 0 & $3.512(1.861-6.630)$ \\
Health Officer Support & 0,998 & 0,001 & $2.712(1.531-4.801)$ \\
Knowledge & 0,707 & 0,018 & $2.027(1.129-3.639)$ \\
Constant & -2.664 & .000 & \\
\hline
\end{tabular}

The treatment adherence equation model is as follows:

$$
\begin{gathered}
\text { Treatment adherence }=-2,664+0.707(\text { knowledge })+1.269(\text { perceived } \\
\text { benefits })+1.256(\text { family support })+0.998(\text { Health worker support })
\end{gathered}
$$

Provided support by health workers can be in the form of morale, for example giving encouragement to complete treatment and playing an active role in-home visits if the patient does not take medication so that health workers who have a high work ethic are needed to overcome this tuberculosis disease. 


\section{Discussion}

Based on the results of this study, adherence to the treatment of pulmonary TB patients in Palembang was only $42.8 \%$. This is due to the lack of public knowledge, support from family and health workers as well as the treatment process which takes a long time, so it can increase the risk of transmission by those who have not yet recovered and the possibility of MDR TB in patients who do not adhere to taking medication. The highlight important barriers to TB treatment adherence in this study population and suggest specific interventions that may be beneficial in mitigating high rates of poor treatment. ${ }^{7}$

The results of another study conducted faund on 112 pulmonary TB patients in Aceh Besar found that 52 patients $(53.6 \%)$ of patients with pulmonary TB were adherent to treatment. ${ }^{1}$ The are treatment compliance of pulmonary TB patients by $60 \% .{ }^{8}$ Meanwhile, the research in Palembang City found that $33.2 \%$ of pulmonary TB patients were adherent to treatment. ${ }^{6}$ This indicates the low adherence to treatment in pulmonary TB patients.

From the results of the analysis of the relationship between individual characteristics and compliance with treatment of pulmonary tuberculosis patients in Palembang, it was found that all variables had a statistical test value of $p$ value $>\alpha(0.05)$, this means that there was no relationship between individual characteristics and compliance with tuberculosis patients treated in Palembang. Individual characteristics of tuberculosis patients in Palembang City consisted of treatment adherence dominated by women, namely $45.6 \%$ compared to men, the proportion of adherence to treatment was dominated by the old age group ( $\geq 45$ years), namely $44.4 \%$ compared to young age groups, the proportion of adherence treatment was dominated by married people, namely, $43.6 \%$ compared to unmarried people, the proportion of treatment adherence was dominated by the working group, namely $46.8 \%$ compared to those who did not work, the proportion of treatment adherence was dominated by tuberculosis patients with low education, namely $43.2 \%$ compared higher education.

From the results of the analysis of the relationship between previous behavior and compliance with pulmonary tuberculosis patients in Palembang, it was found that only knowledge variables had a statistical test value of $p$-value $<\alpha(0.05)$. This means that there is a relationship between knowledge and adherence to the treatment of pulmonary tuberculosis patients in Palembang (OR 1.775). With good knowledge of pulmonary TB patients, it can increase adherence by 2 times greater than pulmonary TB patients who have poor knowledge of pulmonary TB at $95 \%$ CI $(1,053-2,991)$.

There was a significant relationship between knowledge and adherence to taking tuberculosis medication at BKPM Pati, meaning that patients with less knowledge have the opportunity to not adhere to taking the medication by 3.857 times. $^{8}$ The results of other studies in accordance on 70 
respondents at BKPM Surakarta showed a positive relationship between the level of knowledge about a disease and pulmonary tuberculosis treatment and the level of adherence to treatment programs $(\mathrm{p}=0.001){ }^{9}$ Knowledge and motivation of tuberculosis (TB) patients will have an impact on compliance in implementing treatment programs ${ }^{10}$. In a study conducted in Palembang, it was stated that there was an influence between knowledge and treatment compliance of pulmonary TB patients. Furthermore, there is statistical Significant difference in Tuberculosis treatment knowledge between defaulters and patients completed a full course of treatment in a rural setting. ${ }^{11}$

Increasing knowledge is something that must be pursued, namely through health promotion about tuberculosis. In order to increase patient knowledge about tuberculosis, it is necessary to promote health by TB Public Health Center officers in providing counseling about tuberculosis to increase public knowledge in general and tuberculosis patients in particular. Kigozi et al found that the need for health education efforts to strengthen accurate information dissemination to promote sound TB knowledge and attitudes among patients attending PHC facilities. ${ }^{12}$ Health education efforts should also capitalise on the positive finding of this study that information dissemination at PHC facilities increases good infection control practices.

From the results of the analysis of the relationship between a specific behavior and compliance with tuberculosis patients in Palembang, it was found that the perceived usefulness and self-efficacy variables had a statistical test value of $p$-value $<\alpha(0.05)$, this means that there is a relationship between perceived benefits and perceptions of self-efficacy with adherence seeking treatment for tuberculosis patients in Palembang. Furthermore, the self-efficacy and level of education have significant influence toward the behavior of self-examination, therefore it can be reference for health practitioner and researcher to promote health behavior among family of patient with Tuberculosis. ${ }^{13}$

In the perceived benefit variable, the OR value obtained is 2.768 , so it can be concluded that pulmonary TB patients who feel the benefit of pulmonary TB disease treatment will be 3 times more obedient than pulmonary TB patients who do not feel any benefit from pulmonary TB disease treatment at $95 \% \mathrm{CI}(1,609-4,760)$.

This study was in line with research that there is a relationship between perceived benefits of treatment compliance for tuberculosis patients with a P-value of 0.019 and $\mathrm{OR}=5.814$. Patients will find it easier to carry out and undergo complete treatment if the patient feels the benefits of treatment, especially a complete recovery from the disease they suffer. If the patient feels that the treatment being carried out is not useful, the patient tends to not comply with the treatment rules so that there will be non-adherence to the treatment. In conclusion, Patients' perceptions of TB have reflected indicators of perceived resistance and self-efficacy significantly affect treatment compliance. $^{2} 14$ 
In the perception of self-efficacy, the OR value is 2.243 , so it can be concluded that tuberculosis patients who have a good perception of self-efficacy towards tuberculosis treatment will be 2 times more obedient than tuberculosis patients who do not have a good self-efficacy perception of tuberculosis treatment at $95 \%$ CI $(1,253-4,014)$. Perception of self-efficacy, namely the perception of being able to help itself to recover from a disease. The belief in healing can be grown from the intention of each tuberculosis patient to get well. Health promotion and education need to be provided in order to provide understanding, knowledge, and explanation about tuberculosis so that there will be changes in attitudes and behavior of tuberculosis patients in undergoing treatment.

The results of the analysis of the relationship between interpersonal influence and compliance with treatment of tuberculosis patients in Palembang, it was found that the variable family support and health worker support had a statistical test value of $p$-value $<\alpha(0.05)$ and $\mathrm{OR}$ 2,985 treatment compliance. That's why supporting patients during medication program of tuberculosis is needed to improve their adherence medication during multidrug therapy. ${ }^{15}$ Family support covered informational support, instrumental support, emotional support, and appraisal support needed tuberculosis patients, including support of nutrition fulfillment. ${ }^{16}$ Furthermore, aspects of social support which include family support, peer group support and support from health workers have an important role and become a driving factor for TB patients to adhere to the treatment regimen. For further research, the development of interventions to improve adherence to TB patients needs to consider these social aspects. ${ }^{17}$

The results of research that support this research, showed that there was a significant relationship between family support and compliance with tuberculosis medication at BKPM Patidan, that family support that lacked the opportunity to not comply with medication was 5,800 times. The results on 134 respondents at the Eradication of Lung Disease (BP4) or Karangtembok Hospital Surabaya showed that there was a relationship between family support and increasing compliance with drinking OAT in tuberculosis patients $(\mathrm{p}=0.001) .{ }^{8}{ }^{18}$ This result is inversely proportional to the other research in Palembang City, it was found that there was no effect between family support and treatment compliance. ${ }^{6}$ The difference in the results obtained may be a change in behavior and the patient's desire to get family support while undergoing a treatment period. A patient who gets support from his family will be more enthusiastic in undergoing treatment, especially if the family can pay more attention and remind him to take medication for 6 months so that it can be concluded that pulmonary TB patients who receive support from health workers in the treatment of pulmonary TB disease are 3 times more compliant than pulmonary TB patients who did not get the support of health workers in the treatment of pulmonary TB disease at $95 \% \mathrm{CI}$ $(1,681-5,084)$. 
Family support, socioeconomic, physician and nurse support, availability to access health services, social stigma, psychological stress, and knowledge were significant factors of the successful treatment of tuberculosis. ${ }^{19}$ Another results showed there was a significant relationship between family support (emotional, material, and informational support) with medical compliance of patients with pulmonary tuberculosis. ${ }^{20}$ It is suggested for health professionals to always promote the importance of family support for the successful of medical treatment among tuberculosis patients. ${ }^{21}$ Furthermore, support provided by health workers can be in the form of morale, for example giving encouragement to complete treatment and playing an active role inhome visits if the patient does not take medication so that health workers who have a high work ethic are needed to overcome this tuberculosis disease. ${ }^{6,22}$ It is necessary to conduct a home visit program by health personnel for patients who are not compliant to check phlegm and conduct further research for health service factors. ${ }^{23}$

Beside that, strong social support within a patient's family, community, or health care context can help counteract structural and personal barriers to adherence by influencing motivation or knowledge and beliefs about TB. However, lack of support or knowledge about TB and its treatment in a patient's family, community, or health care context, as well as real or perceived stigmatization of the sick, can hinder adherence. ${ }^{24}$ The results proved that peer group support could affect the medication time adherence on pulmonary tuberculosis patients. It can be concluded that peer group support can be used as an optional intervention to increase the obedience of pulmonary tuberculosis treatment in patients. ${ }^{25}$

\section{Conclusion}

The description of adherence to treatment of tuberculosis patients in Palembang was only $42.8 \%$. There is a relationship between perceived benefits, family support, support from health workers, knowledge with compliance with tuberculosis patient treatment in Palembang City. The most important determinant of adherence is perceived benefit with a 3.556 times greater opportunity after controlling for other variables

\section{Acknowledgment}

The researcher would like to thanks for our supervisor and team of this thesis Research Examination Commission, which has taken the time to attend the exam and provide input to perfect the thesis written by the researcher, also for All public health center has facilitated providing patient data and addresses of TB patients, making it easier to conduct interviews with patients' homes.

\section{Funding}

There is no funding for this research, and the funds used are the author's personal funds. 


\section{Conflict of Interest}

There is no conflict of interest in this study.

\section{References}

1. Marzuki. Faktor-Faktor yang Berhubungan Dengan Kepatuhan Berobat Penderita Tuberculosis Paru di Puskesmas dalam Wilayah Kabupaten Aceh Besar 1998. Universitas Indonesia, Depok. 2002.

2. Aisyah. Hubungan Persepsi, Pengetahuan TB Paru, dan PMO dengan Kepatuhan Berobat Pasien TB Paru di Puskesmas Kecamatan Jatinegara Jakarta Timur. Tesis. Universitas Indonesia, Depok. 2001.

3. Rahmansyah A. Faktor-Faktor yang Berhubungan dengan Drop Out (DO) pada Penderita TB Paru di Rumah Sakit Paru Palembang Tahun 2010. Tesis. Universitas Indonesia, Depok. 2012.

4. Departemen Kesehatan Republik Indonesia. Pedoman Nasional Penanggulangan Tuberkulosis. Departemen Kesehatan Republik Indonesia. Jakarta: 2002.

5. Lameshow S., Hosmers., Klar J., Lwanga S K. Besar Sampel Dalam Penelitian Kesehatan (Terjemahan). Yogyakarta: UGM. 1997.

6. Syafrida. Determinan Kepatuhan Berobat Pasien TB Paru di Puskesmas Dalam Wilayah Kota Palembang Tahun 2010. Tesis. Program Pascasarjana Stikes Bina Husada, Palembang. 2010.

7. Aibana O, Dauria E, Kiriazova T, et al. Patients' perspectives of tuberculosis treatment challenges and barriers to treatment adherence in Ukraine: a qualitative study. BMJ Open. 2020;10(1):e032027. Published 2020 Feb 2. doi:10.1136/bmjopen-2019-032027

8. Dhewi, GI. Hubungan Natara Pengetahuan, Sikap Pasien, dan Dukungan Keluarga Dengan Kepatuhan Minum Obat Pasien TB Paru di BKPM Pati. Semarang: 2012

9. Safri F M. Faktor Yang Berhubungan Dengan Kepatuhan Minum Obat Pasien TB Berdasarkan Health Belief Model di Wilayah Kerja Puskesmas Umbul Sari. Universitas Airlangga, Jember. 2013.

10.Sukartini T., Widianingrum T R., dan Yasmara D. The Relationship of Knowledge and Motivation Tuberculosis Drug Compliance in Tuberculosis. A Multifaceted Review Journal in The Field of Pharmacy. 2020; Vol 11 (6) : 603-606.

11.Elsading YM., Hashim E A A H., Abdalla S M., Saleem G A G., Sami W., Elbadawi T E., Medani K A., dan Ahmed S M. The Impact of Knowledge on Adherence to Tuberculosis Treatment: A Case-Control Study form a Rural Setting. EC Pulmonology and Respiratory Medicine. 2018; Vol 7 (12): 830-834.

12.Kigozi N G., Heunis J C., Engelbrecht M. C., Janse van Rensburg A. P., dan Van Rensburg H. Tuberculosis Knowledge, Attitudes And Practices Of Patients At Primary Health Care Facilities 
In A South African Metropolitan: Research Towards Improved Health Education. BMC Public Health. 2017; Vol 17 (1) : 795.

13. Ahmadi dan Hakim A R. Self-Efficacy And Selected Demographics As Determinants Of The Family Behavior On Examination For Patients With Tuberculosis In Pamekasan. International Conference Of Kerta Cendekia Nursing Academy. 2019; Vol 1 (1): 122-132.

14.Zainal S M, Sapar, Syafruddin, dan Irwandy. The effect of patients' perception about tuberculosis (TB) against treatment compliance. Pubmed. 2020; Vol (2): 416-419. doi: 10.1016/j.enfcli.2019.07.128. PMID: 32204201.

15. Ratnasari NY, Husna PH, Marni, Nurtanti S, Susanto T. Adherence to Medication Behavior Among Tuberculosis Patients and Their Affecting Factors: A Cross-Sectional Study at Public Health Center of Wonogiri District, Indonesia. Front Nurs. 2020; Vol 7 (3): 279-286. doi: 10.2478/FON-2020-0024

16. Suprajitno S dan Ningsih N R. Family Support for The Fulfillment of Nutrition of Tuberculosis Patients. Journal of Ners and Midwifery. 2018; Vol. 5 (3): 178-181. doi: 10.26699/jnk.v5i3.ART.p178-181

17. Barik A L, Indarwati R, dan Sulistiawati. The Role Of Social Support On Treatment Adherence In TB Patients: A Systematic Review. Nurse and Health: Jurnal Keperawatan. 2020; Vol 9 (2): 201-210.

18. Hutapea. Pengaruh Dukungan Keluarga Terhadap Kepatuhan Minum Obat Anti Tuberkulosis. RSUD Dr. Saiful Anwar Malang. 2006.

19.Ridi Putra K W dan Toonsiri C. Factors Related to The Successful Treatment of Tuberculosis: A Literatur Review. Belitung Nursing Journal.2019; Vol 5 (3): 136-146. doi: 10.33546/bnj.749

20.Fleischhacker W, Oehl M A dan Hummer M. Factor Influencing Compliance Patient. Journal Clinical Psychiatry. 2003; 64 Suppl 16:10-3. PMID: 14680413.

21. Mongan R dan Fajar. Relationship Between Family Support And Medical Compliance In Patients With Pulmonary Tuberculosis In The Working Area Of The Community Health Center Of Abeli, Kendari. Public Health of Indonesia-YCAB Publisher. 2017; Vol 3 (1): 1722. https://doi.org/10.36685/phi.v3i1.111

22.Perdana P. Faktor-Faktor Yang Berhubungan dengan Kepatuhan Berobat Penderita TB Paru Di Puskesmas Kecamatan Ciracas. Jakarta Timur: FIIK Universitas Pembangunan Nasional. 2008

23.Ruditya D N. The Relationship Between Characteristic Of Tuberculosis Patient With Compliance In Check A Sputum During Treatment. Jurnal Berkala Epidemiologi. 2015; Vol 3 (2): 122-133.

24.DiStefano M J dan Schmidt H. mHealth for Tuberculosis Treatment Adherence: A Framework to Guide Ethical Planning, Implementation, and Evaluation. Global Health: Ccience and Practice Journal. 2016; Vol. 4 (2): 211-221. 
25.U Hasanah., M Makhfudi., L Ni'mah., F Efendi., dan Aurizki E. Peer Group Support on the Treatment Adherence of Pulmonary Tuberculosis Patients. IOP Conference Series: Earth and Environmental Science. 2019. doi:10.1088/1755-1315/246/1/012033 